\title{
Suillus collinitus methanolic extract increases p53 expression and causes cell cycle arrest and apoptosis in a breast cancer cell line
}

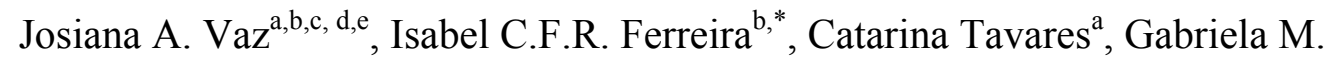

Almeida $^{\mathrm{a}}$, Anabela Martins ${ }^{\mathrm{b}}, \mathrm{M}$. Helena Vasconcelos ${ }^{\mathrm{a}, \mathrm{e}}$

${ }^{a}$ Cancer Drug Resistance Group, IPATIMUP - Institute of Molecular Pathology and Immunology of the University of Porto, Portugal.

${ }^{\mathrm{b}}$ CIMO- Mountain Research Centre, School of Agriculture, Polytechnic Institute of Bragança, Campus de Santa Apolónia, Apartado 1172, 5301-855 Bragança, Portugal.

${ }^{\mathrm{c}}$ CEQUIMED-UP - Center of Medicinal Chemistry-University of Porto, Portugal.

${ }^{\mathrm{d}}$ Health School, Polytechnic Institute of Bragança, Av. D. Afonso V, 5300-121 Bragança, Portugal.

e Department of Biological Sciences, Laboratory of Microbiology, Faculty of Pharmacy, University of Porto, Portugal.

* Author to whom correspondence should be addressed (e-mail: iferreira@ipb.pt telephone +351-273-303219; fax +351-273-325405). 


\begin{abstract}
In the present work, methanolic, ethanolic and boiled water extracts of Suillus collinitus were chemically characterized and further submitted to evaluation of their bioactive properties (antioxidant potential and cytotoxic activity in tumor cell lines). Phenolic acids and sugars were chromatographically identified and quantified in the methanolic and boiled water extracts, respectively. $S$. collinitus ethanolic extract gave the highest antioxidant activity. Nevertheless, regarding cell growth inhibition, the methanolic extract was the most potent one, particularly in MCF-7 cells $\left(\mathrm{GI}_{50} 25.2 \pm 0.2 \mu \mathrm{g} / \mathrm{ml}\right)$. Moreover, the $\mathrm{GI}_{50}$ concentration induced a G1 cell cycle arrest, with a concomitant decrease in the percentage of cells in the $\mathrm{S}$ phase. Furthermore, it caused an increase in the percentage of apoptotic cells, from $6.0 \pm 0.2 \%$ in untreated cells, to $15.3 \pm 2.0 \%$ in cells treated with the $\mathrm{GI}_{50}$ concentration and to $16.3 \pm 2.0 \%$ in cells treated with $2 \times \mathrm{GI}_{50}$ concentration. In addition, $48 \mathrm{~h}$ treatment with the $\mathrm{GI}_{50}$ concentration caused a strong increase in the levels of p53, p21, and cleaved PARP, together with a decrease in Bcl-2 and XIAP. Results indicate that Suillus collinitus may be a promising source of bioactive compounds. Particularly, its methanolic extract appears to have a p53mediated effect on the normal cell cycle distribution and apoptosis induction in a human breast tumor cell line.
\end{abstract}

Keywords: Wild mushroom; antioxidant potential; breast cancer; apoptosis induction; p53-mediated effect 


\section{Introduction}

Cancer has become a major public health problem in Europe with an estimated prevalence of about 3\%, increasing to $15 \%$ at old age. Moreover, cancer related deaths are projected to increase to over 11 million in 2030 (World Health Organization, 2010). Breast cancer is the major health problem in women worldwide, regarding both its incidence and mortality, which is emphasised by the diagnosis of over one million new cases annually (Botha, Bray, Sankila, \& Parkin, 2003; Ferlay et al., 2007; Ferlay et al., 2008; Stankov \& Stankov, 2011). Indeed, breast cancer is the most frequently diagnosed cancer and the leading cause of cancer death among females, accounting for $23 \%$ of the total cancer cases and 14\% of the cancer deaths (Jemal et al., 2011).

Mushrooms are part of the sexual life cycle of particular fungi with specific metabolic pathways, and therefore may contain a largely unexploited source of powerful new pharmaceutical products with potential antitumor properties. Furthermore, they may have potential as functional foods (Borchers, Keen, \& Gershwin, 2004; Ferreira, Vaz, Vasconcelos, \& Martins, 2010; Moradali, Mostafavi, Ghods, \& Hedjaroude, 2007; Zaidman, Yassin, Mahajana, \& Wasser, 2005). The most important molecules found in mushrooms with antitumor potential include polysaccharides and phenolic compounds or derivatives (Ferreira et al., 2010; Liu et al., 2009; Vaz, Almeida, Ferreira, Martins, \& Vasconcelos, 2012; Wasser, 2002; Zhang, Cui, Cheung, \& Wang, 2007; Zhou \& Chen, 2011). Furthermore, the antioxidant activity of the latter has been extensively reported, namely as free radical inhibitors (chain breaker), peroxide decomposers, metal inactivators or oxygen scavengers (Ferreira, Barros, \& Abreu, 2009; Palacios et al., 2011). Suillin, a derivative of a phenolic acid (protocatechuic acid) belonging to the prenylphenols class isolated from the mushroom Suillus placidus, has proven to be a 
potent apoptosis inducer in human hepatoma HepG2 cells (Liu et al., 2009). Like $S$. placidus, Suillus collinitus is also an edible mycorrhizal mushroom found in European pine forests, belonging to the same genus Suillus in the Suillaceae family. Nevertheless, to the best of our knowledge there is no report of antitumour potential for this mushroom species.

In the present work, methanolic, ethanolic and boiled water extracts of $S$. collinitus were submitted to bioactivity evaluation through in vitro antioxidant potential (mainly free radical scavenging activity and reducing power) and cytotoxic activity in various tumor cell lines: lung, breast, colon and gastric cancer. The extracts were chemically characterized in their phenolic acids and sugars composition by chromatographic techniques. The extract with highest cells growth inhibitory activity (methanolic extract) was chosen to be further investigated regarding its possible mechanism of action in the most susceptible cell line studied (breast cancer), by cell cycle and apoptosis evaluation. Furthermore, being etoposide one of the major standard cytotoxic drugs used in polychemotherapy, its concomitant use with $S$. collinitus methanolic extract was also studied in the same cells.

\section{Materials and methods}

\subsection{Standards and reagents}

Acetonitrile $99.9 \%$ was of HPLC grade from Lab-Scan (Lisbon, Portugal). All the other solvents and chemicals were of analytical grade purity. Ethanol was supplied by Pronalab (Lisbon, Portugal). Sugar standards $(\mathrm{L}(+)$-arabinose, $\mathrm{D}(-)$-fructose, $\mathrm{D}(+)-$ mannitol and $\mathrm{D}(+)$-trehalose) were purchased from Sigma (St. Louis, MO, USA). 2,2Diphenyl-1-picrylhydrazyl (DPPH) was obtained from Alfa Aesar (Ward Hill, MA, USA). Water was treated in a Milli-Q water purification system (TGI Pure Water 
Systems, USA). Fetal bovine serum (FBS), L-glutamine, phosphate buffer saline (PBS), trypsin and RNase A were from Gibco Invitrogen Co. (Paisley, UK). RPMI-1640 medium was from Lonza (Basel, Switzerland). Acetic acid, dimethylsulfoxide (DMSO), sulforhodamine B (SRB), trypan blue, propidium iodide (PI) and phenolic standards were from Sigma Chemical Co. (St. Louis, USA). Trichloroacetic acid (TCA) and Tris were sourced from Merck (Darmstadt, Germany). Primary and secondary antibodies were from Santa Cruz Biotechnology Inc. (Heidelberg, Germany).

\subsection{Samples and preparation of the extracts}

Samples of Suillus collinitus (Fr.) Kuntz (edible mushroom) were collected in Bragança (Northeast Portugal). Taxonomic identification of sporocarps was made according to Coutecuisse \& Duhem (2005) and representative voucher specimens were deposited at the herbarium of Escola Superior Agrária of Instituto Politécnico de Bragança. The

samples were lyophilised (Ly-8-FM-ULE, Snijders, Holland) and reduced to a fine powder (20 mesh).

Methanolic, ethanolic and boiled water extracts were prepared from the lyophilised powder following the procedure previously described by us (Vaz et al., 2010). For the antioxidant activity assays, each extract was re-dissolved in the corresponding solvent, while for the tumour cell growth screening assays, the extracts were re-dissolved in DMSO (a stock solution was prepared and then further diluted until the determination of $\mathrm{GI}_{50}$ values). Final concentration of DMSO showed no interference with the biological activity tested. The solutions were stored at $-20^{\circ} \mathrm{C}$ until further use.

\subsection{Chemical characterization of the extracts}


Phenolic acids were analysed by high performance liquid chromatography coupled to a photodiode array detector (HPLC-DAD) according to a previous report of the authors (Vaz et al., 2011a).

Sugars were determined, after crude polysaccharides hydrolysis, by high performance liquid chromatography coupled to a refraction index detector (HPLC-RI) as previously described by the authors (Heleno et al., 2012), using fructose as internal standard (IS). The equipment consisted of an integrated system with a pump (Knauer, Smartline system 1000), degasser system (Smartline manager 5000), auto-sampler (AS-2057 Jasco) and a RI detector (Knauer Smartline 2300). The chromatographic separation was achieved with a Eurospher 100-5 $\mathrm{NH}_{2}$ column $(4.6 \times 250 \mathrm{~mm}, 5 \mu \mathrm{m}$, Knauer $)$ operating at $30{ }^{\circ} \mathrm{C}$ (7971 $\mathrm{R}$ Grace oven). The mobile phase was acetonitrile:deionized water, $70: 30(\mathrm{v} / \mathrm{v})$ at a flow rate of $1 \mathrm{ml} / \mathrm{min}$. Sugars identification and quantification was made according to standards and data were analysed using Clarity 2.4 Software (DataApex). The results are expressed in g per kg of dry weight (dw).

\subsection{Screening of antioxidant activity}

DPPH radical-scavenging activity. This methodology was performed using an ELX800 Microplate Reader (Bio-Tek Instruments, Inc), according to Vaz et al. (2011b). The reaction mixture in each one of the 96-wells consisted of one of the serial concentrations of the extracts $(30 \mu \mathrm{l})$ and aqueous methanolic solution $(80: 20 \mathrm{v} / \mathrm{v}, 270 \mu \mathrm{l})$ containing

DPPH radicals $\left(6 \times 10^{-5}\right.$ mol. $\left.1^{-1}\right)$. The mixture was left to stand for $60 \mathrm{~min}$ in the dark. The reduction of the DPPH radical was determined by measuring the absorption at 515 $\mathrm{nm}$. The radical scavenging activity (RSA) was calculated as a percentage of DPPH discolouration using the equation: \% RSA $=\left[\left(\mathrm{A}_{\mathrm{DPPH}}-\mathrm{A}_{\mathrm{S}}\right) / \mathrm{A}_{\mathrm{DPPH}}\right] \times 100$, where $\mathrm{A}_{\mathrm{S}}$ is the absorbance of the solution when the sample extract has been added at a particular level, 
and $\mathrm{A}_{\mathrm{DPPH}}$ is the absorbance of the DPPH solution. The extract concentration providing $50 \%$ of radicals scavenging activity $\left(\mathrm{EC}_{50}\right)$ was calculated from the graph of RSA percentage against extract concentration. Trolox (6-hydroxy-2,5,7,8tetramethylchroman-2-carboxylic acid) was used as standard.

Reducing power. The serial concentrations of the extracts $(0.5 \mathrm{ml})$ were mixed with sodium phosphate buffer (200 mmol. $\mathrm{l}^{-1}$, $\mathrm{pH}$ 6.6, $\left.0.5 \mathrm{ml}\right)$ and potassium ferricyanide (1 $\% \mathrm{w} / \mathrm{v}, 0.5 \mathrm{ml})$. The mixture was incubated at $50{ }^{\circ} \mathrm{C}$ for $20 \mathrm{~min}$, and trichloroacetic acid $(10 \% \mathrm{w} / \mathrm{v}, 0.5 \mathrm{ml})$ was added. The mixture $(0.8 \mathrm{ml})$ was poured in the 48 -wells, as also deionised water $(0.8 \mathrm{ml})$ and ferric chloride $(0.1 \% \mathrm{w} / \mathrm{v}, 0.16 \mathrm{ml})$, and the absorbance was measured at $690 \mathrm{~nm}$ in the Microplate Reader described above (Vaz et al., 2011b). The extract concentration providing 0.5 of absorbance $\left(\mathrm{EC}_{50}\right)$ was calculated from the graph of absorbance at $690 \mathrm{~nm}$ against extract concentration. Trolox was used as standard.

Inhibition of $\beta$-carotene bleaching. The antioxidant activity of the extracts was evaluated by the $\beta$-carotene linoleate model system. A solution of $\beta$-carotene was prepared by dissolving $\beta$-carotene $(2 \mathrm{mg})$ in chloroform $(10 \mathrm{ml})$. Two millilitres of this solution were added to a $100 \mathrm{ml}$ round-bottom flask. After the chloroform was removed at $40{ }^{\circ} \mathrm{C}$ under vacuum, linoleic acid (40 mg), Tween ${ }^{\circledR} 80$ emulsifier (400 mg), and distilled water $(100 \mathrm{ml})$ were added to the flask and vigorously shaken. Aliquots $(4.8$ $\mathrm{ml}$ ) of this emulsion were transferred into different test tubes containing serial concentrations $(0.2 \mathrm{ml})$ of the extracts. The tubes were shaken and incubated at $50{ }^{\circ} \mathrm{C}$ in a water bath (Vaz et al., 2011b). As soon as the emulsion was added to each tube, the zero time absorbance at $470 \mathrm{~nm}$ was measured. Inhibition of $\beta$-carotene bleaching was 
calculated using the following equation: Absorbance after $2 \mathrm{~h}$ of assay/Initial Absorbance $) \times 100$. The extract concentration providing $50 \%$ antioxidant activity $\left(\mathrm{EC}_{50}\right)$ was calculated by interpolation from the graph of antioxidant activity percentage against extract concentration. Trolox was used as standard.

\subsection{Screening of growth inhibition activity in human tumour cell lines}

The effects of the extracts on the growth of human tumour cell lines was evaluated according to the procedure adopted in the NCI's in vitro anticancer drug screening, which uses sulforhodamine B (SRB) assay to assess cell growth inhibition (Skehan et al., 1990). Four human tumour cell lines were used: NCI-H460 (lung cancer), MCF-7 (breast cancer), HCT-15 (colon cancer) and AGS (gastric cancer). Cells were routinely maintained as adherent cell cultures in RPMI-1640 medium containing 5\% heatinactivated FBS at $37{ }^{\circ} \mathrm{C}$, in a humidified air incubator containing $5 \% \mathrm{CO}_{2}$. Each cell line was plated at an appropriate density $\left(5.0 \times 10^{3}\right.$ cells/well for NCI-H460 and MCF7, $1.0 \times 10^{4}$ cells/well for HCT-15 and $7.5 \times 10^{3}$ cells/well for AGS) in 96-well plates and allowed to attach for $24 \mathrm{~h}$. Cells were then treated for $48 \mathrm{~h}$ with various extract concentrations. The DMSO concentrations used ( 0.2 to $0.8 \%)$ have no growth inhibitory effect in these cell lines.

Following this incubation period, the adherent cells were fixed with $10 \%$ trichloroacetic acid (final concentration), stained with SRB and excess dye washed with $1 \%$ acetic acid. The bound SRB was solubilised with $10 \mathrm{mM}$ Tris and the absorbance was measured at $490 \mathrm{~nm}$ in a microplate reader (Multi-mode microplate synergy ${ }^{\mathrm{TM}} \mathrm{MX}$, Biotek) and analysed with the Gen5 $5^{\mathrm{TM}}$ software (Biotek). The concentration that inhibited growth in 50\% (GI $\left.{ }_{50}\right)$ was calculated as described by Monks et al. (1991). The growth inhibitory activity of the extracts was inferred from the SRB assay by comparing 
the absorbance of the wells containing extract-treated cells with the absorbance of the wells containing untreated cells, $48 \mathrm{~h}$ following treatment with the extracts, and subsequently comparing these results with the ones obtained for cells that had been fixed at time zero (time at which extracts were added).

\subsection{Cell cycle distribution analysis and apoptosis detection}

For the analysis of cell cycle phase distribution, MCF-7 cells were plated at $1.5 \times 10^{5}$ cells $/ \mathrm{ml}$ in 6 -well plates and left incubating for 24 hours. Cells were then incubated with complete medium (blank), or with $S$. collinitus methanolic extract at the $\mathrm{GI}_{50}$ and $2 \times \mathrm{GI}_{50}$ concentrations. The DMSO concentrations used have no effect on the cell cycle profile. Cells were harvested following a $48 \mathrm{~h}$ incubation period with the extract and further processed for either cell cycle analysis or apoptosis detection. For cell cycle analysis, cells were fixed in $70 \%$ ethanol and kept at $4{ }^{\circ} \mathrm{C}$ until analysis. Prior to analysis, cells were incubated with PI $(5 \mu \mathrm{g} / \mathrm{ml})$ and RNase A in PBS $(100 \mu \mathrm{g} / \mathrm{ml})$ for $30 \mathrm{~min}$ on ice (Vaz et al., 2012). Apoptosis was assayed with the Human Annexin V-FITC/PI apoptosis Kit (Bender MedSystems, Vienna, Austria) according to the manufacturer's instructions, as previously described by us (Queiroz et al., 2010).

Cellular DNA content (for cell cycle distribution analysis and presence of sub-G1 peak, which is suggestive of apoptosis induction) and measurement of phosphatidylserine externalization (for apoptosis detection) were analyzed using an Epics XL-MCL Coulter flow cytometer plotting at least 20,000 events per sample. Cell cycle distribution and apoptosis data analysis were subsequently performed using the FlowJo 7.2 software (Queiroz et al., 2010).

\subsection{Protein expression analysis}


For analysis of protein expression, MCF-7 cells were treated with complete medium (blank), or with $S$. collinitus methanolic extract at the $\mathrm{GI}_{50}$ and $2 \times \mathrm{GI}_{50}$ concentration, and processed $48 \mathrm{~h}$ after incubation. DMSO controls were also tested. Cells were lysed in Winman's buffer (1\% NP-40, $0.1 \mathrm{M}$ Tris-HCl $\mathrm{pH} 8.0,0.15 \mathrm{M} \mathrm{NaCl}$ and $5 \mathrm{mM}$ EDTA) with EDTA-free protease inhibitor cocktail (Boehringer, Mannheim, Germany). Proteins were quantified using the DC Protein Assay Kit (BioRad, Hercules, CA, USA) and separated in $12 \%$ tris-glycine sodium dodecyl sulfate (SDS)-polyacrylamide gel. Proteins were then transferred to a nitro-cellulose membrane (GE Healthcare, Madrid, Spain). The membranes were incubated with the following primary antibodies for poly (ADP-ribose) polymerase (PARP) (1:4000), p53 (1:200), XIAP (1:1000), Bcl2 (1:100), p21 (1:200) and Actin (1:2000), and further incubated with the appropriate secondary antibodies conjugated with horseradish peroxidase (HRP) diluted 1:2000 in 5\% non-fat dried milk in T-TBS. The signal was detected with the Amersham ECL kit (GE Healthcare) using the Hyperfilm ECL (GE Healthcare) and the Kodak GBX developer and fixer twin pack (Sigma) (Vaz et al., 2012).

2.8. Cell growth inhibition following treatment of cells concomitantly with etoposide and $S$. collinitus methanolic extract

The effects of the concomitant use of etoposide and S. collinitus methanolic extract on the growth of MCF-7 cells was evaluated according to the procedure previously described in section 2.5. Etoposide was used at $1 \mu \mathrm{M}$ (approximately the $\mathrm{GI}_{50}$ concentration in this cell line, previously determined), and the extract was used at the previously determined $\mathrm{GI}_{50}$ concentration.

\subsection{Statistical analysis}


For each assay 3 to 6 independent experiments were performed in triplicate (antioxidant activity assays) or duplicate (antitumour activity assays), and the results were expressed as mean values \pm standard deviation (SD) or standard error (SEM). One-way analysis of variance (ANOVA) followed by Tukey's HSD Test was performed with the SPSS v.16.0 software. Differences in $p$ values bellow 0.05 were considered statistically significant.

\section{Results and discussion}

\subsection{Chemical characterization and screening of bioactive properties}

The methanolic and boiled water (after hydrolysis of crude polysaccharides with trifluoroacetic acid) extracts were analyzed by HPLC-DAD and HPLC-RI, respectively and the results are given in Table 1. Two phenolic acids, $p$-hydroxybenzoic and protocatechuic acids, and one related compound, cinnamic acid, were found. Regarding sugars composition, mannitol, arabinose and trehalose were identified and quantified in

\section{S. collinitus (Figure 1).}

Three different assays were carried out for the in vitro evaluation of the antioxidant properties of the methanolic, ethanolic and boiled water extracts: scavenging activity on DPPH radicals, inhibition of lipid peroxidation in a $\beta$-carotene-linoleate system and reducing power. The methanolic extract revealed the lowest antioxidant activity (highest $\mathrm{EC}_{50}$ values; extract concentration that achieves $50 \%$ of antioxidant activity or 0.5 of reducing power) in all the assays (Table 2). The antioxidant properties of ethanolic and boiled water extracts were similar (without significant statistical differences), except for reducing power which was higher in the ethanolic extract $(1.3 \mathrm{mg} / \mathrm{ml}$, Table 2$)$. The observed antioxidant potential might be related to the phenolic acids found (Table 1) and their reported chemoprotective effects against oxidative stress-mediated disorders 
mainly from their free radical scavenging and metal chelating properties (Soobrattee, Neergheen, Luximon-Ramma, Aruoma, \& Bahorun, 2005).

The effects of the $S$. collinitus extracts on the growth of four human tumour cell lines (NCI-H460, MCF-7, HCT-15 and AGS), represented as the concentrations that caused $50 \%$ of cell growth inhibition $\left(\mathrm{GI}_{50}\right)$, are summarized in Table 3. The methanolic extract was the most potent in all tested cell lines, presenting $\mathrm{GI}_{50}$ values that ranged from 25.2 to $103.2 \mu \mathrm{g} / \mathrm{ml}$ for the MCF-7 and HCT-15 cells, respectively. Its activity could be related to the phenolic compounds found in the extract who have already demonstrated capacity to decrease viable cells number, mostly when they are concomitantly used (Vaz et al., 2012).

The boiled water extract did not show any effect on the cell lines at the tested concentrations (up to $400 \mu \mathrm{g} / \mathrm{ml}$ ), as it can be observed, for example, in the doseresponse effect of the three extracts on MCF-7 cell line (Figure 2).

MCF-7 cell line was the most susceptible (presenting the lowest $\mathrm{GI}_{50}$ ) to $S$. collinitus methanolic extracts. Therefore, this most active extract was chosen to be further investigated regarding its possible mechanism of action in this cell line.

\subsection{Effects on cell cycle profile and apoptosis induction}

The MCF-7 cell line was incubated with the $\mathrm{GI}_{50}(25.2 \mu \mathrm{g} / \mathrm{ml})$ or twice the $\mathrm{GI}_{50}(50.4$ $\mu \mathrm{g} / \mathrm{ml})$ concentrations of the mushroom's extract for $48 \mathrm{~h}$ and their effects on the normal cell cycle distribution and induction of apoptosis were studied.

Analysis of the effect of the methanolic extract on cell cycle was performed by flow cytometry and results show that both the $\mathrm{GI}_{50}$ concentration and $2 \times \mathrm{GI}_{50}$ concentration induced a G1 cell cycle arrest, with a concomitant decrease in the percentage of cells in the S phase (Figure 3). 
Additionally, it was investigated whether $S$. collinitus induced apoptosis in the MCF-7 cell line, using the annexin V-FICT/PI flow cytometry assay. MCF-7 cells treated with the methanolic extract for $48 \mathrm{~h}$ presented an increase in the percentage of apoptotic cells, from $6.0 \pm 0.2 \%$ in untreated cells, to $15.3 \pm 2.0 \%$ in cells treated with the $\mathrm{GI}_{50}$ concentration and to $16.3 \pm 2.0 \%$ in cells treated with $2 \times \mathrm{GI}_{50}$ concentration (Table 4).

Furthermore, the effect of the mushroom extract on the expression of some proteins involved in the apoptotic process was determined by Western blot. Results show that treatment of MCF-7 cells with the $\mathrm{GI}_{50}$ concentration of the extract caused a strong increase in the levels of $\mathrm{p} 53$. This effect was even stronger when cells were treated with $2 \times \mathrm{GI}_{50}$ concentration, suggesting that the effect is concentration-dependent. Accordingly, the levels of p21 whose expression is regulated by p53 and related to cell cycle arrest were also increased in a concentration dependent manner with the $\mathrm{GI}_{50}$ and with the $2 \times \mathrm{GI}_{50}$ concentrations. Finally, treatment of the cells with the extract caused a decrease in the levels of XIAP and Bcl-2 and a concentration dependent increase in the levels of cleaved PARP, which are consistent with an apoptotic process of cell death (Figure 4).

Etoposide is one of the major standard cytotoxic drugs used for different cancers and frequently used in polychemotherapy. Therefore, the effect of treating MCF-7 cells concomitantly with $S$. collinitus (methanolic extract) and etoposide was also studied, by verifying the $\%$ of cell growth upon a $48 \mathrm{~h}$ incubation with the previously determined approximate $\mathrm{GI}_{50}$ concentration of etoposide $(1 \mu \mathrm{M})$ and with the $\mathrm{GI}_{50}(25.2 \mu \mathrm{g} / \mathrm{ml})$ of the extract. The combined use of the methanolic extract and etoposide caused a greater decrease in the $\%$ of cell growth, when compared to either of them used individually, indicating the potential benefit of this combination (Figure 5). 
Overall, the S. collinitus ethanolic extract gave highest scavenging properties and reducing power, while the methanolic extract was the most potent inhibiting the growth of tumour cell lines (NCI-H460, MCF-7, HCT-15 and AGS).

Natural antioxidants may have different means for exerting their action, including interactions with intracellular signal transduction pathways or inducing the expression of antioxidant and detoxification enzymes. In this context, it is becoming now more evident that the pro-oxidant effect, rather than the antioxidant, is the key event at the basis of antiproliferative effect exerted by natural antioxidants on the cells (Chen et al., 2008; Ullah et al., 2011; Weisburg et al, 2010; Zhang et al., 2010). Nevertheless, within the present study it is not clear if antioxidant or pro-oxidant effects are related to antiproliferative activity. Based on the in vitro assays performed, only antioxidant effects were found: mainly scavenging activity and reducing power. Apparently, there is no correlation between both activities (in vitro antioxidant activity and antiproliferative activity using human cells), because ethanolic extract revealed the highest antioxidant potential, while methanolic extract gave the highest antiproliferative activity.

MCF-7 cells were the most susceptible of the cells studied, and the methanolic extract appears to have a p53-mediated effect on the normal cell cycle distribution and apoptosis induction in these cells. Suillus collinitus is a promising source of bioactive compounds, however further studies will be necessary such as analysis of its effect in non-tumour cells and the isolation and identification of the compounds present in the methanolic extract which may be responsible for the obtained results. Nonetheless, it is possible that the activity here described may be caused by the combination of several compounds and not by any individually isolated compound.

\section{Acknowledgements}


The authors are grateful to Fundação para a Ciência e a Tecnologia (FCT, Portugal) and COMPETE/QREN/EU for financial support to this work (research project PTDC/AGRALI/110062/2009) and to CIMO (strategic project PEst-OE/AGR/UI0690/2011). They also thank to University of Porto and Santander Totta for financial support. J.A Vaz thanks to FCT, POPH-QREN and FSE for her grant (BD/43653/2008). G.M. Almeida is supported by FCT and the European Social Fund. IPATIMUP is an Associate Laboratory of the Portuguese Ministry of Science, Technology and Higher Education and is partially supported by FCT.

\section{References}

Borchers, A.T., Keen, C.L., \& Gershwin, M.E. (2004). Mushrooms, tumors, and immunity: An update. Experimental Biology and Medicine, 229, 393-406.

Botha, J.L., Bray, F., Sankila, R., \& Parkin, D.M. (2003). Breast cancer incidence and mortality trends in 16 European countries. European Journal of Cancer, 39, $1718-1729$.

Chen, Q., Espey, M.G., Sun, A.Y., Pooput, C., Kirk, K.L., Krishna, M.C., Khosh, D.B., Drisko, J., \& Levine, M. (2008). Pharmacologic doses of ascorbate act as a prooxidant and decrease growth of aggressive tumor xenografts in mice. Proceedings of the National Academy of Sciences USA, 105, 11105-11109.

Courtecuisse, R., \& Duhem, B. (2005). Guía de los hongos de la Peninsula Ibérica, Europa y Norte de África. Barcelona: Ediciones Omega.

Ferlay, J., Autier, P., Boniol, M., Heanue, M., Colombet, M., \& Boyle, P. (2007). Estimates of the cancer incidence and mortality in Europe in 2006. Annals of Oncology, 18, 581-92. 
Ferlay, J., Shin, H.R., Bray, F., Formen, D., Mathers, C., \& Parkin, D.M. GLOBOCAN (2008). Cancer incidence and mortality worldwide: IARC CancerBase $\mathrm{n}^{\mathrm{o}} 10$ [Internet]. Lyon France: International Agency for Research on Cancer.

Ferreira, I.C.F.R., Barros, L., \& Abreu, R.M.V. (2009). Antioxidants in wild mushrooms. Current Medicinal Chemistry, 16, 1543-1560.

Ferreira, I.C.F.R., Vaz, J.A., Vasconcelos, M.H., \& Martins, A. (2010). Compounds from wild mushrooms with antitumor potential. Anti-cancer Agents in Medicinal Chemistry, 10, 424-436.

Heleno, S.A., Barros, L., Martins, A., Queiroz, M.J.R.P., Santos-Buelga, C., \& Ferreira, I.C.F.R. (2012). Fruiting body, spores and in vitro produced mycelium of Ganoderma lucidum from Northeast Portugal: A comparative study of the antioxidant potential of phenolic and polysaccharidic extracts. Food Research International, 46, 135-140.

Jemal, A., Bray, F., Center, M.M., Ferlay, J., Ward, E., Forman, D. (2011). Global Cancer Statistics. CA Cancer Journal for Clinicians, 61, 69-90.

Karim-Kos, H.E., Vries, E., Soerjomataram, I., Lemmens, V., Siesling, S., \& Coebergh, J.W.C. (2008). Recent trends of cancer in Europe: A combined approach of incidence, survival and mortality for 17 cancer sites since the 1990s. European Journal of Cancer, 44, 1345-1389.

Liu, F.-Y., Luo, K.-W., Yu, Z.-M, Co, N.-N., Wu, S.-H., Wu, P.W., Fung, K.-P., \& Kwok, T.-T. (2009). Suillin from the mushroom Suillus placidus as potent apoptosis inducer in human hepatoma HepG2 cells. Chemico-Biological Interactions, 181, 168-174.

Queiroz, M.-J.R.P., Calhelha, R.C., Vale-Silva, L.A., Pinto, E., Lima, R.T., Vasconcelos, M.H.. (2010). Efficient synthesis of 6-(hetero)arylthieno[3,2- 
b]pyridines by Suzuki\&\#8211;Miyaura coupling. Evaluation of growth inhibition on human tumor cell lines, SARs and effects on the cell cycle. European Journal of Medicinal Chemistry, 45, 5628-5634.

Moradali, M.-F., Mostafavi, H., Ghods, S., \& Hedjaroude, G.-A. (2007). Immunomodulating and anticancer agents in the realm of macromycetes fungi (macrofungi). International Immunopharmacology, 7, 701-724.

Monks, A., Scudiero, D., Skehan, P., Shoemaker, R., Paull, K., Vistica, D., Hose, C., Langley, J., Cronise, P., Vaigro-Wolff, A., Gray-Goodrich, M., Campbell, H., Mayo, J., \& Boyd, M. (1991). Feasibility of a high-flux anticancer drug screen using a diverse panel of cultured human tumor cell lines. Journal of the National Cancer Institute, 83, 757-766.

Palacios, I., Lozano, M., Moro, C., D’Arrigo, M., Rostagno, M.A., Martínez, J.A., García-Lafuente, A. Guillamón, E., \& Villares, A. (2011). Antioxidant properties of phenolic compounds occuring in edible mushrooms. Food Chemistry, 128, 674-678.

Skehan, P., Storeng, R., Scudiero, D., Monks, A., MacMahon, J., Vistica, D., Warren, J.T., Bokesch, H., Kenney, S., \& Boyd, M.R. (1990). New colorimetric cytotoxicity assay for anticancer-drug screening. Journal of the National Cancer Institute, 82, 1107-1112.

Soobrattee, M.A., Neergheen, V.S., Luximon-Ramma, A., Aruoma, O.I., \& Bahorun T. (2005). Phenolics as potential antioxidant therapeutic agents: mechanism and actions. Mutation Research, 579, 200-213.

Stankov, S., \& Stankov, K. (2011). Descriptive epidemiology of breast cancer in Vojvodina. The Breast, 20, 192-195. 
Ullah, M.F., Ahmad, A., Khan, H.Y., Zubair, H., Sarkar, F.H., \& Hadi, S.M. (2011). The prooxidant action of dietary antioxidants leading to cellular DNA breakage and anticancer effects: implications for chemotherapeutic action against cancer. Cell Biochemistry and Biophysics. DOI: 10.1007/s12013-011-9303-4.

Vaz, J.A., Almeida, G.M., Ferreira, I.C.F.R., Martins, A., \& Vasconcelos, M.H. (2012). Clitocybe alexandri extract induces cell cycle arrest and apoptosis in a lung cancer cell line: identification of phenolic acids with cytotoxic potential. Food Chemistry, $132,482-486$.

Vaz, J.A., Barros, L., Martins, A., Morais, J.S., Vasconcelos, M.H., \& Ferreira, I.C.F.R. (2011a). Phenolic profile of seventeen Portuguese wild mushrooms. LWT- Food Science and Technology, 44, 343-346.

Vaz, J.A., Barros, L., Martins, A., Santos-Buelga, C., Vasconcelos, M.H., \& Ferreira, I.C.F.R. (2011b). Chemical composition of wild edible mushrooms and antioxidant properties of their water soluble polysaccharidic and ethanolic fractions. Food Chemistry, 126, 610-616.

Vaz, J.A., Heleno, S.A., Martins, A., Almeida, G.M., Vasconcelos, M.H., \& Ferreira, I.C.F.R. (2010). Wild mushrooms Clitocybe alexandri and Lepista inversa: In vitro antioxidant activity and growth inhibition of human tumour cell lines. Food and Chemical Toxicology, 48, 2881-2884.

Wasser, S.P. (2002). Medicinal mushrooms as a source of antitumor and immunomodulating polysaccharides. Applied Microbiology and Biotechnology, $60,258-274$.

Weisburg, J.H., Schuck, A.G., Silverman, M.S., Ovits-Levy, C.G., Solodokin, L.J., Zuckerbraun, H.L., \& Babich, H (2010). Pomegranate extract, a prooxidant with 
antiproliferative and proapoptotic activities preferentially towards carcinoma cells. Anticancer Agents in Medicinal Chemistry, 10, 634-44.

World Health Organization. (2010). WHO Library Cataloguing-in-Publication Data World health statistics 2010. 1.Health status indicators. 2.World health. 3.Health services-statistics. 4.Mortality. 5.Morbidity. 6.Life expectancy.7.Demography. 8.Statistics. I. World Health Organization. ISBN 9789241563987 (NLM classification: WA 900.1).

Zaidman, B.-Z., Yassin, M., Mahajana, J., \& Wasser, S.P. (2005). Medicinal mushroom modulators of molecular targets as cancer therapeutics. Applied Microbiology and Biotechnology, 67, 453-468.

Zhang, H., Cao, D., Cui, W., Ji, M., Qian, X., \& Zhong, L. (2010). Molecular bases of thioredoxin and thioredoxin reductase-mediated prooxidant actions of (-)epigallocatechin-3-gallate. Free Radical Biology \& Medicine, 49, 2010-2018.

Zhang, M., Cui, S.W., Cheung, P.C.K., \& Wang, Q. (2007). Antitumor polysaccharides from mushrooms: A review on their isolation process, structural characteristics and antitumor activity. Trends in Food Science and Technology, 18, 4-19.

Zhou, L.-B., \& Chen, B. (2011). Bioactivities of water-soluble polysaccharides from Jisongrong mushroom: anti-breast carcinoma cell and antioxidant potential. International Journal of Biological Macromolecules, 48, 1-4. 
Table 1. Phenolic acids, derivatives and sugars (after crude polysaccharides hydrolysis) in the Suillus collinitus extracts.

\begin{tabular}{llc}
\hline & Protocatechuic acid & $5.2 \pm 0.2$ \\
-Methanolic extract* & $p$-Hydroxybenzoic acid & $14.1 \pm 1.2$ \\
& Cinnamic acid & $1.3 \pm 0.2$ \\
- & Arabinose & $30.3 \pm 5.5$ \\
Boiled water extract & Mannitol & $32.2 \pm 4.1$ \\
& Trehalose & $11.0 \pm 0.2$ \\
\hline
\end{tabular}

Results are expressed in $\mathrm{mg} / \mathrm{kg}$ (phenolic acids) or $\mathrm{g} / \mathrm{kg}$ (sugars) in dry weight basis, and show means \pm SD of 3 independent experiments performed in triplicate. ${ }^{*}$ Vaz et al., 2011. 
Table 2. Antioxidant activity of Suillus collinitus extracts.

\begin{tabular}{|c|c|c|c|}
\hline Extracts & DPPH scavenging activity & $\beta$-carotene bleaching inhibition & Reducing power \\
\hline Methanolic* & $14.1 \pm 1.2^{\mathrm{a}}$ & $1.2 \pm 0.1^{\mathrm{a}}$ & $3.0 \pm 0.0^{\mathrm{a}}$ \\
\hline Ethanolic & $7.3 \pm 0.7^{b}$ & $1.2 \pm 0.1^{\mathrm{a}}$ & $1.3 \pm 0.0^{\mathrm{c}}$ \\
\hline Boiled water & $7.9 \pm 0.5^{\mathrm{b}}$ & $1.2 \pm 0.0^{\mathrm{a}}$ & $2.1 \pm 0.0^{\mathrm{b}}$ \\
\hline
\end{tabular}

Results are expressed as $\mathrm{EC}_{50}$ (concentration of extract in $\mathrm{mg} / \mathrm{ml}$ that cause $50 \%$ of antioxidant activity or 0.5 of absorbance in the reducing power assay), and show means $\pm \mathrm{SD}$ of 3 independent experiments performed in triplicate. In each column, different letters mean significant differences between results $(p<0.05) . *$ Heleno et al., 2010. 
Table 3. Growth inhibitory activity of Suillus collinitus extracts on human tumour cell lines.

\begin{tabular}{lcccc}
\hline \multicolumn{1}{c}{ Extracts } & NCI-H460 & MCF-7 & HCT-15 & AGS \\
& (lung cancer) & (breast cancer) & (colon cancer) & (gastric cancer) \\
\hline Methanolic & $62.5 \pm 6.3^{\mathrm{b}}$ & $25.2 \pm 0.16^{\mathrm{b}}$ & $103.2 \pm 9.9^{\mathrm{b}}$ & $79.2 \pm 15.5^{\mathrm{b}}$ \\
Ethanolic & $253.7 \pm 2.3^{\mathrm{a}}$ & $101.8 \pm 8.9^{\mathrm{a}}$ & $139.4 \pm 34.1^{\mathrm{a}}$ & $170.7 \pm 35^{\mathrm{a}}$ \\
Boiled water & $>400$ & $>400$ & $>400$ & $>400$ \\
\hline
\end{tabular}

Results are expressed as $\mathrm{GI}_{50}$ (concentration of extract in $\mu \mathrm{g} / \mathrm{ml}$ that cause $50 \%$ of cell growth inhibition), and show means \pm SD of 3-6 independent experiments performed in duplicate. In each column, different letters mean significant differences between results $(p<0.05)$. 
Table 4. Percentage of apoptotic MCF-7 cells induced by the methanolic extract of Suillus collinitus.

\begin{tabular}{llll}
\hline & Blank & $\mathrm{GI}_{50}$ & $2 \times \mathrm{GI}_{50}$ \\
\hline Apoptotic cells (\%) & $6.0 \pm 0.2^{\mathrm{b}}$ & $15.3 \pm 2.0^{\mathrm{a}}$ & $16.3 \pm 2.0^{\mathrm{a}}$ \\
\hline
\end{tabular}

Results are the mean \pm SD of at least 3 independent experiments, performed in duplicate. In the row, different letters mean significant differences between results $(p<0.05)$. 


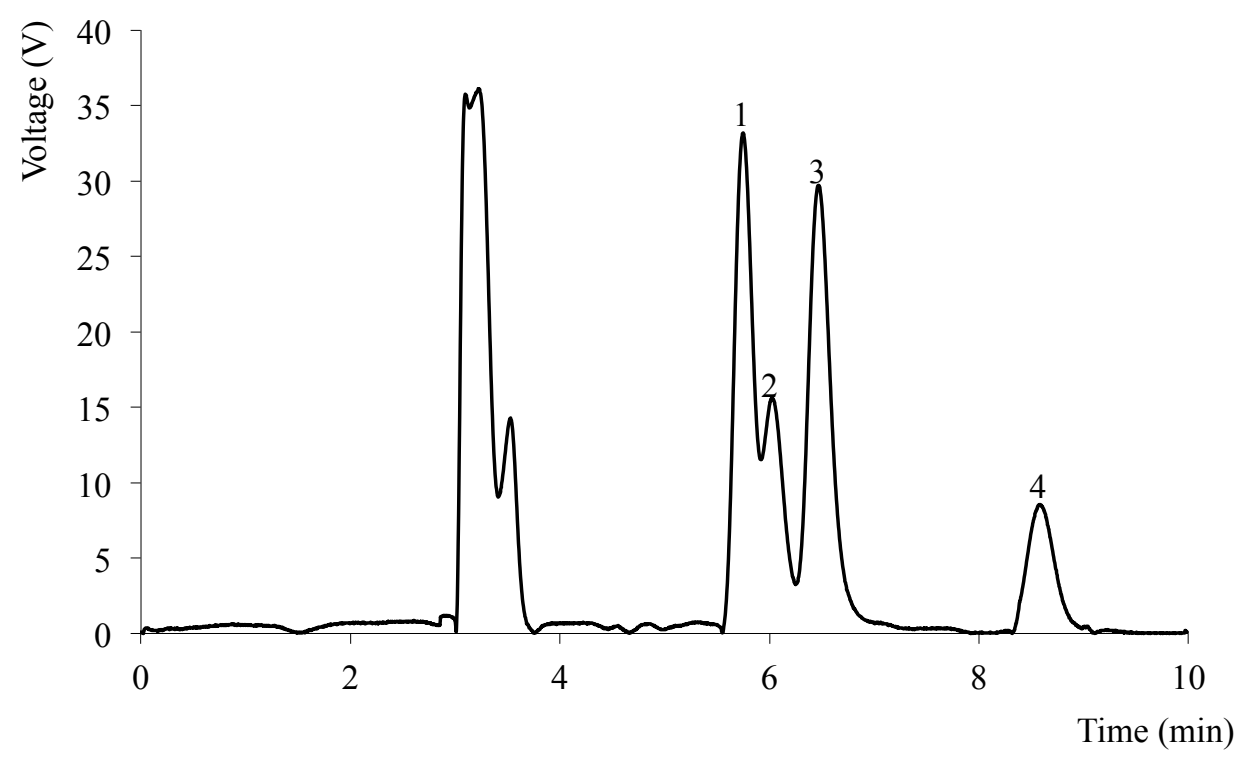

Figure 1. Sugars profile of Suillus collinitus obtained by HPLC-RI. 1. Arabinose; 2Fructose (IS); 3- Mannitol; 4- Trehalose. 


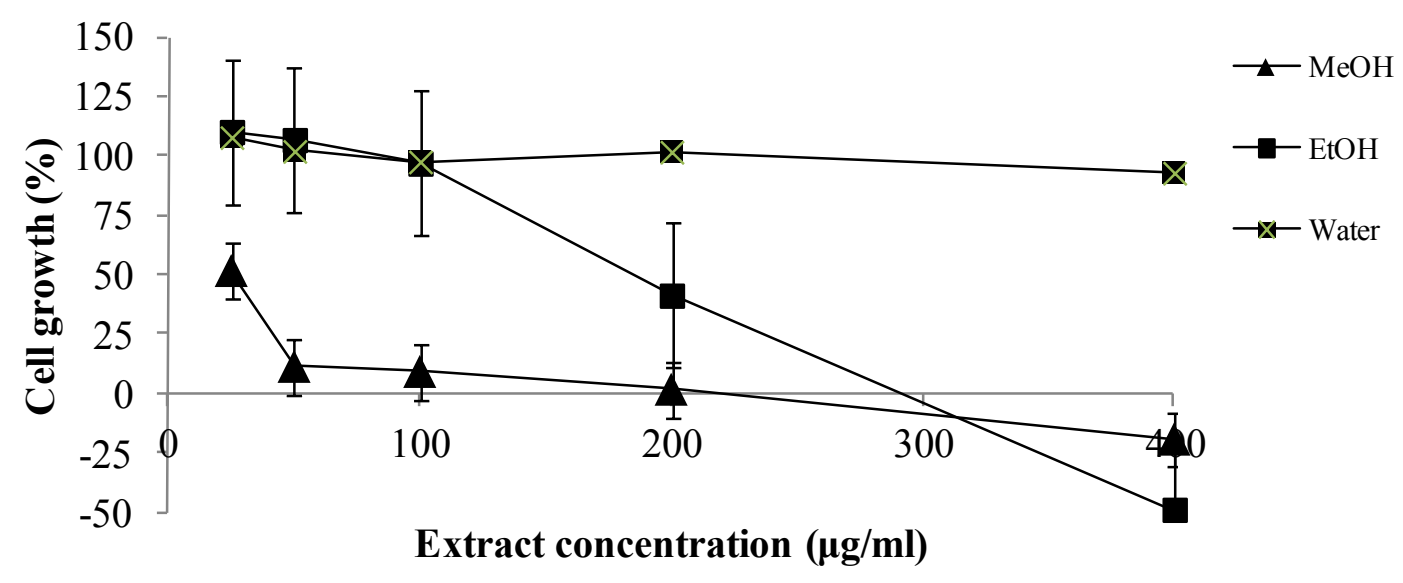

Figure 2. Percentage of cell growth of the methanolic $(\mathrm{MeOH})$, ethanolic $(\mathrm{EtOH})$ and boiled water extracts of Suillus collinitus against MCF-7 cells. Results are the mean \pm SD of at least three independent experiments, performed in duplicate. 


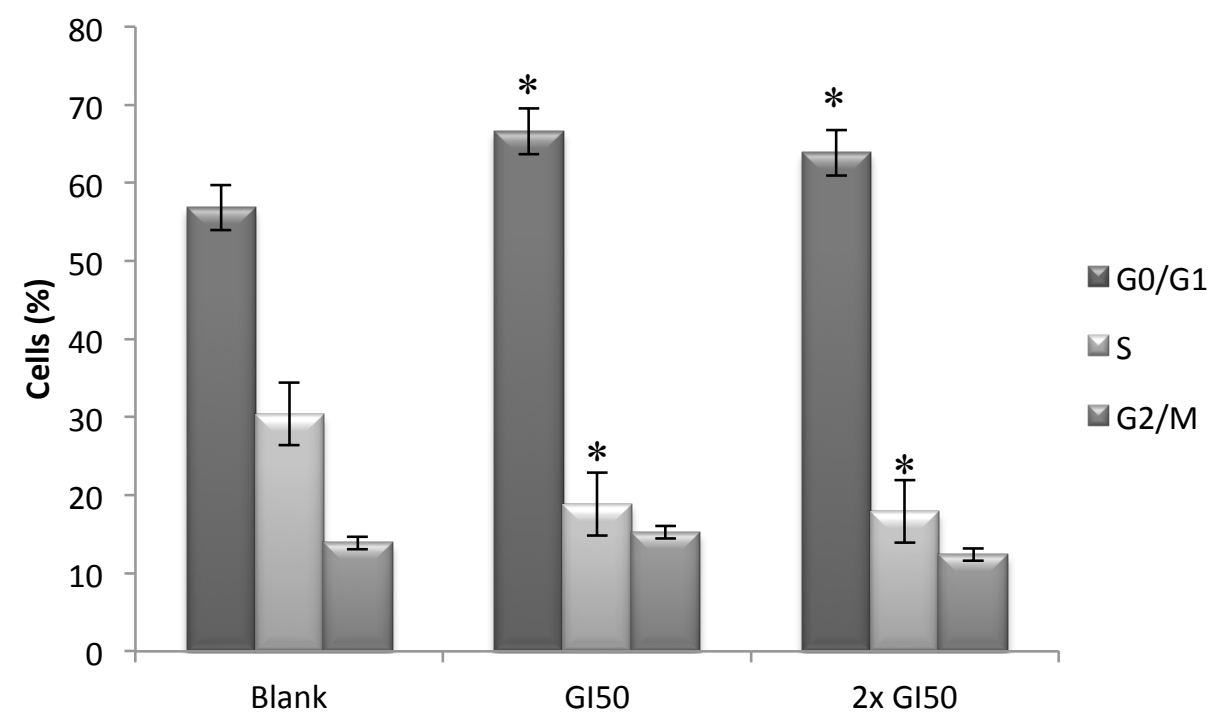

Figure 3. Treatment of MCF-7 cells with the methanolic extract of Suillus collinitus increases the $\%$ cells in G1 and decreases de \% cells in the S phase of the cell cycle.

Cell cycle analysis of MCF-7 cells treated for $48 \mathrm{~h}$ with the methanolic extract of Suillus collinitus at $\mathrm{GI}_{50}(25.2 \mu \mathrm{g} / \mathrm{ml})$ or twice the $\mathrm{GI}_{50}(50.4 \mu \mathrm{g} / \mathrm{ml})$ concentrations. Untreated cells were used as control (blank). Results are the means \pm SEM of 3-6 independent experiments performed in duplicate. *Statistically significant different values when compared to blank $(p<0.05)$. 

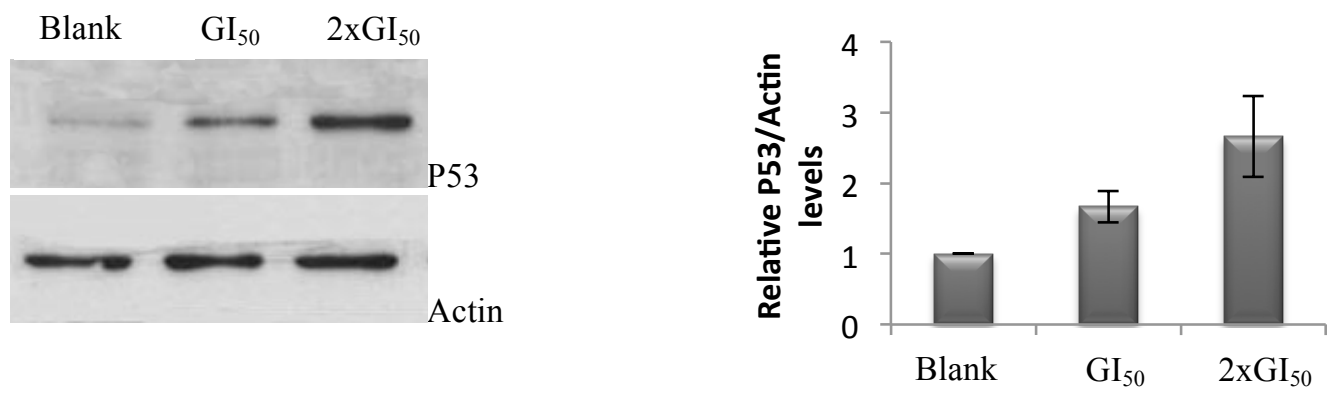

D553

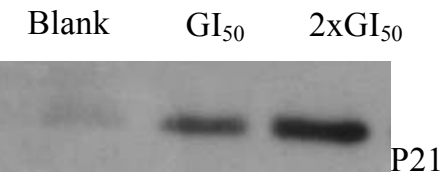

Actin
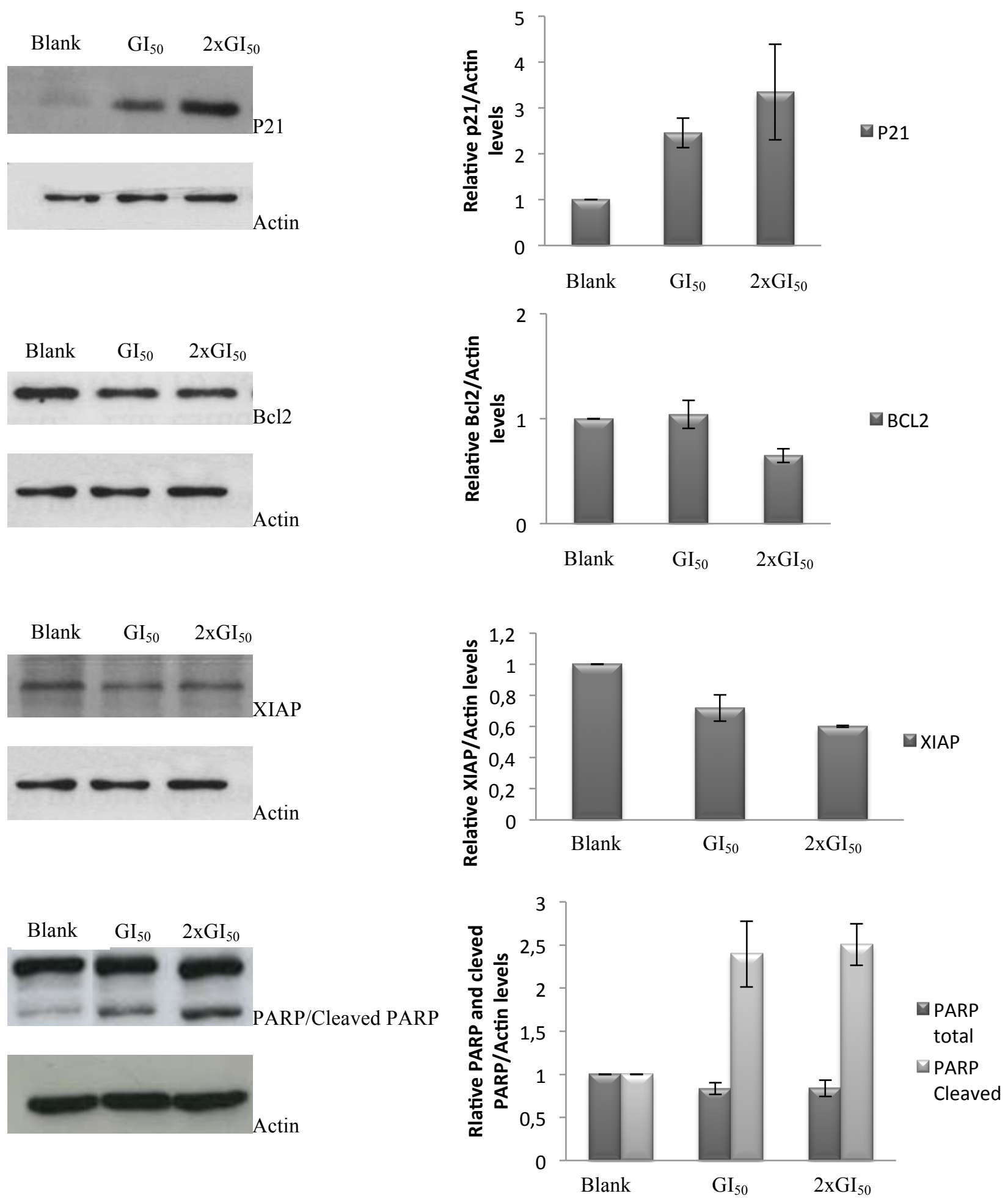
Figure 4. Treatment of MCF-7 cells with the methanolic extract of Suillus collinitus increases p53 levels and PARP cleavage. MCF-7 cells were treated for $48 \mathrm{~h}$ with complete medium (blank) or with the extract at $\mathrm{GI}_{50}$ concentration $(25.2 \mu \mathrm{g} / \mathrm{ml})$ or $2 \times \mathrm{GI}_{50}$ concentration $(50.4 \mu \mathrm{g} / \mathrm{ml})$. Actin was used as a loading control. DMSO controls had no effect on the expression of the studied proteins. Results are representative of 3 independent experiments. 


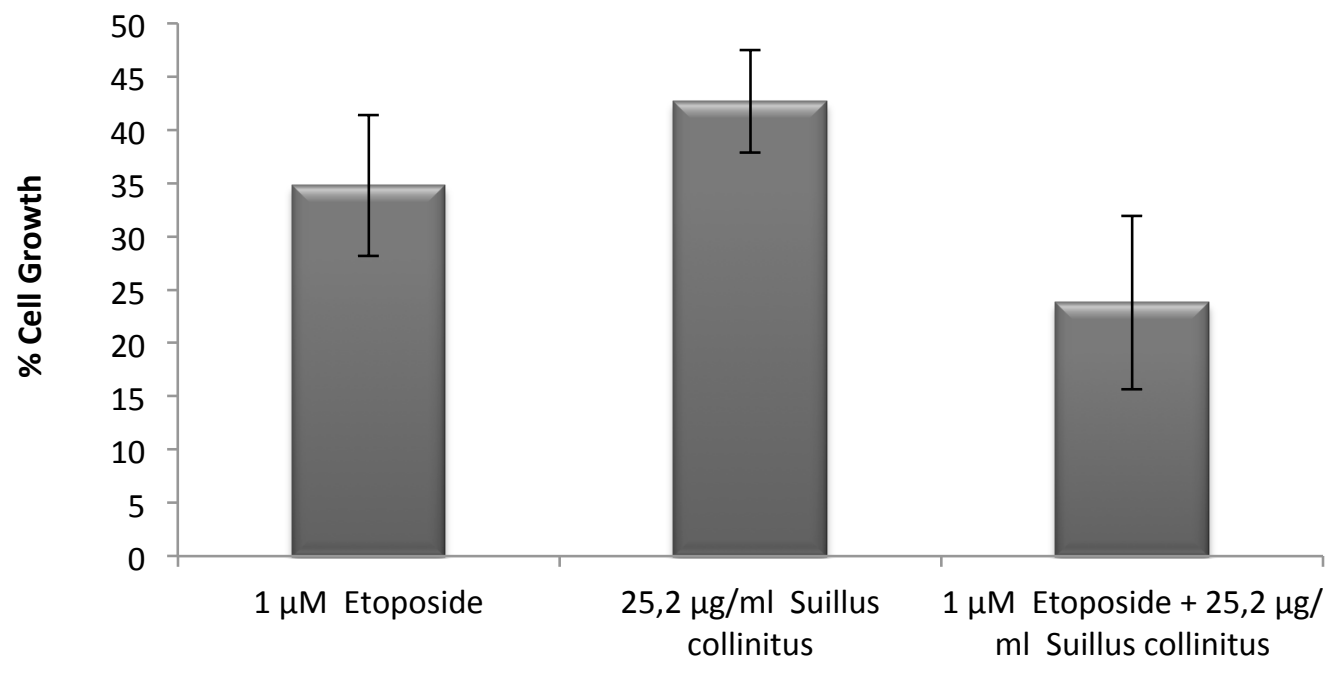

Figure 5. Treatment of MCF-7 cells concomitantly with etoposide and Suillus collinitus (methanolic extract) has a greater cell growth inhibitory effect than treatment with either of them alone. MCF-7 cells were treated with $1 \mu \mathrm{M}$ of etoposide, $25.2 \mu \mathrm{g} / \mathrm{ml}$ of the methanolic extract of $S$. collinitus or with both together. Cell growth inhibitory activity was confirmed with the SRB assay. Appropriate DMSO controls had no effect on cell growth. Values are the mean of 4 independent experiments \pm S.E. 